\title{
Analysis of the Effect of the Implementation of the Quantum Teaching Method on Accounting Learning in Class XI IPS SMA N 1 Laguboti
}

\author{
Blasius Erik Sibarani \\ State University of Medan \\ e-mail: blasiussibarani@gmail.com
}

Sibarani, B. E. (2021). Analysis of the Effect of the Implementation of the Quantum Teaching Method on Accounting Learning in Class XI IPS SMA N 1 Laguboti. Aptisi Transactions on Technopreneurship (ATT), 3(1), 1-12.

\begin{abstract}
Learning methods are one of the keys to the success of teaching and learning and the key to achieving learning goals. Learning methods are ways that are used to implement plans that have been prepared in the form of real and practical activities to achieve learning goals, namely a method chosen by educators to optimize the teaching and learning process that aims to achieve the expected learning goals. A classroom learning will take place well and smoothly if learning is designed with interesting learning methods and increase students enthusiasm to receive lessons. Nowadays there are many teaching and learning activities in class that make students bored and lazy because KBM runs monotonously so that teaching and learning is just finished without the achievement of learning objectives. Accounting learning is a lesson that focuses on calculations, emphasizes detail, sincerity, understanding, and accounting is always related to the word balance. Therefore, accounting learning must be designed in such a way and as attractive as possible so that students can be serious in accepting lessons so that learning does not take place for free. This study aims to obtain an overview of how the influence of the implementation of the quantum teaching method on the teaching and learning process in the classroom and to determine the effectiveness of using this method in accounting lessons. Data collection techniques in this study are questionnaires, participatory observation, field notes. The data analysis technique in this study is descriptive quantitative data analysis.
\end{abstract}

Keywords: Accounting Learning, Learning Methods, Quantum Teaching

\section{Introduction}

Education is the main actor in shaping the human personality, education is also the accessibility of humans to gain broad insights and knowledge. Without education, human knowledge will not be able to develop quickly. Thus, that is why the government is very aggressively evaluating every education system, because with a good education system it is hoped that the future generations of the nation will have quality and are able to adapt to live in society, as a nation and as a state.

According to Law no. 20 of 2003, education is a conscious and planned effort to create an atmosphere of learning and the learning process so that students actively develop their potential to have religious spiritual strength, self-control, personality, intelligence, noble character, and skills needed by themselves, society, the nation, and country. Meanwhile, according to Wina 
Sanjaya (2013: 3), education is an effort to develop the potential of students. Children must be viewed as organisms that are developing and have various potentials, therefore, education must be directed to develop the potential of students. Learning must be student-oriented and place students as learning subjects. As learning subjects, students must be active in doing. RI Law No. 20 of 2003 Article 3 concerning the National Education System (2003: 7) reads:

National Education functions to develop abilities, form a dignified national character and civilization in order to educate the nation's life, aims to develop students' potential to become human beings who believe, fear God Almighty, have noble character, are healthy, knowledgeable, capable, creative, independent, and become a democratic and responsible citizen.

According to Suryadi and Mushlih (2019: 25) "learning is part of the educational process". This statement is in line with the opinion of Fatmawati, et al. (2015: 4) which states that "the success or failure of educational attainment depends on how learning is experienced by students in school". So we can conclude that learning is part of the educational process undertaken by students and educational staff.

The education system will run well and be directed if learning is carried out properly which is supported by interactive learning methods. Without the application of interactive and interactive learning methods, teaching and learning will be monotonous and boring. This cannot be separated from the activities of students who provide positive feedback on learning activities in class.

According to Sardiman AM (2011: 95-97) activity is the most important aspect of learning, because in essence learning is an activity. Hamalik (2009: 179) Learning activities are activities carried out by students in learning activities. Therefore, a learning process must have learning activities so that the objectives of learning can be achieved and students can understand the lessons given. Without learning activities, learning will not be able to run as expected but will run in vain and do not provide outcomes for students. Paul D. Dierech (2011) divides the types of learning activities into eight, including: (1) visual activities; (2) oral activity; (3) listening activity; (4) writing activities; (5) drawing activities; (6) activity metrics; (7) mental activity; and (8) emotional activity. Thus, in learning there must be learning activities, as well as accounting learning.

According to the Ministry of National Education (2003: 6), accounting is a study of a system to produce information regarding financial transactions. Accounting learning is the process of making people learn or a series of events that affect students so that the learning process can take place easily to convey a set of teaching material based on the scientific foundation of accounting that will be taught to students as learning loads through certain methods and approaches. Accounting Subjects are part of productive subjects, at SMA Negeri 1 Laguboti which are taught in accordance with the Minimum Requirements Criteria listed in the K13 Curriculum which are adjusted to the conditions of SMA Negeri 1 Laguboti for the 2018/2019 Academic Year. Based on observations of the ongoing teaching and learning process.

Quantum teachingis a learning process approach that can bring out the natural abilities and talents of students in building an effective learning process (Porter, 2005: 3). Quantum teaching learning model emphasizes techniques to improve self-efficacy and the process of awareness of one's potential.

Based on the background of the problem that has been described, the researcher intends to conduct classroom action research with the title "Analysis of the Effect of the Application of the Quatum Teaching Method on Accounting Learning in Class XI IPS SMA N 1 Laguboti". Formulation of the problem to improve the quality of the learning process, reforms must be made. One of the targets of the renewal is the learning process. Many of the learning processes that occur today are not interactive and are out of date. Updates must be made to improve the quality of learning itself and in the end it will be able to improve the quality of students.

Based on This background, the formulation of the problem in this study is how the influence of the accounting learning model with the quantum teaching method on the accounting learning process. Research Objectives and Benefits.

Analysis of the Effect of the Implementation... 
The purpose of this study is to obtain a description of the accounting learning model with the quantum teaching method and to determine the extent of the effect of the effectiveness of using the accounting learning model with the quantum teaching method on accounting learning. Meanwhile, the benefit of this research is to enrich the knowledge related to education, especially regarding interactive learning methods. In addition, it is also a consideration for educators in determining the learning methods used, especially accounting lessons. For the school, the results of this study can be used as material for consideration in improving the quality of teaching and learning activities and providing alternatives in solving problems in a less interactive learning process, especially for accounting subjects.

\section{Research Method}

A. Quantum Teaching

According to (DePoter, 2010: 32) says that Quantum teaching is a lively change in learning style, with all its nuances. According to Riyanto (2010: 199) Quantum Teaching is a fun change in learning, and includes all connections, interactions and differences that maximize learning moments. Furthermore, according to Wena (2009: 160) Quantum Teaching is a new way of facilitating the learning process by combining artistic elements and directed achievement, which can be applied in all subjects. From the opinions of the experts above, quantum teaching is a learning model that makes the learning atmosphere focused and lively. Quantum teaching emphasizes techniques to improve one's abilities and the process of realizing one's potential.

Some of the steps for learning quantum teaching, namely:

1. Initial conditioning

In order for learning to be carried out well, mental preparation of students regarding this learning model is very important by carrying out activities including: growth, self-confidence, self-motivation, building relationships, and learning skills.

2. Preparation of learning plans

At this stage, the activities carried out are the preparation of tools and other support, the determination of activities during the teaching and learning process, and the preparation of evaluations.

3. Implementation of quantum learning methods

This stage is the core of applying the quantum learning model. Activities in this stage include TANDUR, namely as follows:

a. Interest growth ( $T=$ Grow interest)

The growth of students' interest in learning is done by creating a pleasant learning atmosphere, namely conditioning the class atmosphere to be more relaxed but serious.

b. Giving general experience $(A=$ Natural $)$

In this step, the teacher provides the opportunity for students to share experiences that students have experienced related to the material to be taught, so that there is student interest in learning more about the material to be taught.

c. Name or presentation of material $(\mathrm{N}=$ name)

In this activity the teacher conveys the material to be studied in full after the students tell the experiences that have been obtained, so that in naming students already have provisions and mastery of the material by students can be maximized.

d. Demonstration of student knowledge ( $D=$ Demonstration)

Demonstrations are carried out in order to provide opportunities for students to present the results of independent assignments that have been given by the previous teacher.

e. Repetition performed by students $(U=$ Repeat $)$

Repetition is done by providing opportunities for students to review the material that has been delivered by the teacher.

f. Celebration of student efforts $(R=$ Celebrate $)$

Celebration is a form of motivation carried out by the teacher by giving praise to students who have succeeded or not been successful in answering questions and do not directly 
blame students' incorrect answers.

4. Evaluation

The evaluation is carried out in accordance with the procedures that the teacher had previously planned for the learning process or outcome to see the effectiveness of the learning model used. In the evaluation there is triangulation.

Teaching and Learning Activities

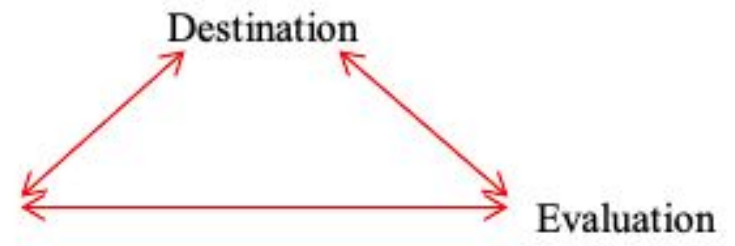

The accounting learning model with the quantum teaching method can be broadly described as follows:

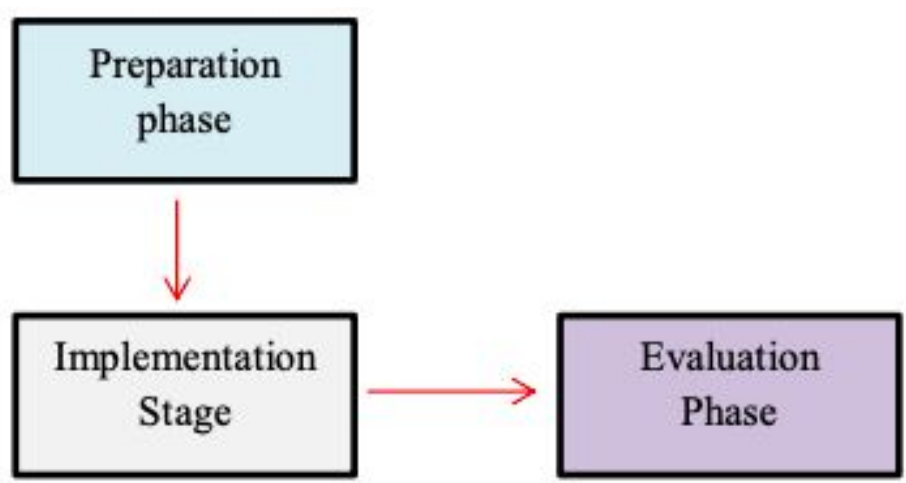

From the plot image above, where the first step is the preparation stage. This preparation stage is where the teacher prepares whatever is needed according to the lesson. After completing the preparation stage, then proceed to the implementation stage. Here the teacher carries out the learning using the method he has prepared. After that, enter the third stage, namely the evaluation stage. In this stage, the teacher evaluates the implementation of learning that has been implemented using the quantum teaching method. Evaluation is not only a teacher, but can also ask for opinions or assessments from their students. Evaluation can also be seen from the learning outcomes of students. Is there an increase in learning with the use of the quantum teaching method or not.

Quantum Teaching focuses on dynamic relationships in the classroom environment (Abdurrahman, Saregar, \& Umam, 2018; DePorter, Bobbi, 2010; Faj, Fakhri, \& Yusandika, 2018; Ningrum, Lesmono, \& Bachtiar, 2017). Quantum Teaching has several principles, including:

1. Everything speaks.

2. Everything from the classroom environment to body language, from the papers being handed out to lesson plans, all send messages about learning.

3. Everything has a purpose.

Everything that happens in our conversion has a purpose.

4. Experience before naming.

Our brains thrive on complex stimuli, which stimulate curiosity. Therefore, the process best occurs when students have obtained information before drawing conclusions from what they have learned. 
5. Acknowledge every effort.

Learning carries risks. Learning means getting out of comfort. When students take this step, they deserve recognition for their competence and confidence.

6. If it's worth studying, it's worth celebrating too.

Celebrations provide feedback on progress and increase interest in learning.

According to Akbar and JA Pramukantoro (2014), the advantages of the quantum teaching model are:

1. Make students feel comfortable and happy in learning, because this model requires every student to always be active in the learning process.

2. Provide motivation to students to take part in ongoing Teaching and Learning Activities.

3. With the opportunity for students to demonstrate their abilities, it will make it easier for teachers to control the extent to which students understand learning While the weaknesses of the quantum teaching model are:

1) The quantum teaching model demands high professionalism from a teacher.

2) he number of media and facilities used is considered less economical.

3) The difficulties faced in using the quantum teaching model will occur in situations and learning conditions that are less conducive so that they require good class mastery.

\section{B. Accounting Learning}

Learning is an activity carried out to create an atmosphere or provide services so that students learn, learning places more emphasis on the teacher in an effort to make students learn not only to make changes in student behavior (Sardiman, 2011: 20-21). According to Komalasari (2010: 3 ) learning is a process that is designed, carried out, and evaluated for students coherently effectively and efficiently in order to get results according to the expected goals. Furthermore, according to Sudjana (2012: 28), learning is an effort made deliberately by educators which can cause students to carry out learning activities. Sagala (2010: 61) states that learning is teaching students using educational principles and learning theory, which is the main determinant of educational success. Learning as a system whose components consist of: students, teachers, objectives, materials, methods, tools / tools, evaluation, environment. Each component is an independent but continuous part and its influence is very important in learning. The completeness of these components is interdependent and affects the results to be achieved in the learning objectives, because to achieve the maximum results from the learning objectives it is necessary to have the completeness of all the components that have been mentioned (Soetopo, 2005: 143).

According to Oemar Hamalik (2001: 77) there are seven aspects in the learning component, namely:

1. Purpose in learning

2. Students / learners

3. Teacher / educator

4. Teaching planning as a curriculum segment

5. Learning strategies

6. Learning Media

7. Learning assessment

According to Thomas Sumarsan (2013: 1), explained that accounting is an art to collect, identify, classify, record transactions and events related to finance, so that it can produce information, namely financial reports that can be used by interested parties. Meanwhile, according to Kieso, et al. (2016: 2) states that accounting is "Accounting consist of the three basic activities - it identifies, records, and communicates the economic events of an organization to interest users. A company identifies the economic events relevant to its business and then records those events in order to provide a history of financial activities. Recording consists of keeping a systematic, 
chronological diary of events, measured in dollar and cents. Finally, communicates the collected information to interest user by means of accounting reports are called financial statements. Furthermore, according to Bahri (2016: 2) explains that the notion of accounting is the art of recording, classifying, summarizing, and reporting on a transaction in such a way, systematically in terms of content, and based on generally recognized standards. From the opinions of the experts above, accounting is an art of recording, grouping, identifying, classifying and reporting that produces information. However, along with the times, where there is a digital transformation from recording books to entering data in software, accounting is not defined as the art of recording anymore. According to the author, the definition of accounting is an action of a transaction that occurs which is then continued into data input, data operations, data processing, grouping, classification, and reporting, which in the end will produce useful financial statement information for interested parties. From the understanding of learning and accounting above, accounting learning is a learning process that takes place in the classroom between teachers and students which discusses accounting material and is supported by the required learning support elements. In accounting learning, there is a process of interaction between students and teachers in the classroom, where they interact with material in accounting.

\section{Findings}

\section{A. Research Population}

According to Uma Sekaran and Roger Bougie (2016: 228) "The reference population to the entire group of people, events, or things of interest that the researcher wishes to investigate. It is the group of people, events, or things of interest for which the researcher wants to make inferences (based on sample statistics)". Population refers to the entire group of people, events, or things of interest that the researcher wants to investigate. It is a group of people, events, or things of interest that the researcher wants to conclude (based on sample statistics). According to Arikunto (2016:173) "The population is the entire research subject". Meanwhile, according to Sugiyono (2018: 130) states that the population is a generalization area consisting of objects / subjects that have certain qualities and characteristics that are determined by researchers to be studied and then draw conclusions. The population in this study were all students of class XI SMAN 1 Laguboti, totaling 280 people.

\section{B. Sample}

According to Uma Sekaran and Roger Bougie (2016: 229) "A sample is a subset of the population. It comprises some members selected from it. In other words, some, but not all, elements of the population form the sampel". "The sample is part of the population. It consists of several members selected from it. In other words, some, but not all, elements of the population make up the sample ". Sampling in this study using simple random sampling technique. The sample in this study amounted to 70 students of class XI SMAN 1 Laguboti.

\section{Method of collecting data}

The data collection method in this study uses the test method. According to Anas Sudijono (2015: 67) a test is a method or procedure in the framework of measurement and assessment, in the form of giving assignments that must be done by a testee, so that on the basis of the data obtained, a value can be generated that symbolizes the behavior or achievement of the testee, the value can be compared with the value. scores achieved by other testees, or compared to certain standard values. The test method in this study was used to obtain data about the achievement of learning achievement from students before and after learning using the quantum teaching method.

Analysis of the Effect of the Implementation... 


\section{Data analysis technique}

This study uses an experimental approach. According to Sugiyono (2017: 72), the experimental research method is a research method used to find the effect of certain treatments on others under controlled conditions. The data analysis was conducted to determine whether there were differences in accounting learning outcomes between classes using the quantum teaching learning model (experimental class) and classes that did not use the quantum teaching learning model (control class). For this reason, the data analysis method used is the t test, namely the Independent Sample T-Test. The difference is indicated by the $t$ test results. If the result value is Sig. (2-tailed) $<0.05$.

\section{E. Results and Discussion}

Respondents in this study amounted to 70 people, where the respondents were divided into two groups, each group numbering 35 people. Group one became the experimental group and group two became the control group. The control group is a group that is not subject to learning using the quantum teaching method, while the experimental group is a group that is subject to learning using the quantum teaching method.

The stages of learning using the quantum teaching method, namely

1. First the planning stage

At this stage the teacher lists the material from the subject to be taught, then writes a list of materials in the form of a brochure on a sheet of paper.

2. The second stage is the implementation stage

At the implementation stage the brochures are installed in the classroom, when the teacher provides information to students about the subjects to be studied, students form groups of five each, the teacher distributes lists of material and accounting lesson modules, when the instrumental music media begins rotated, students study the module and do practice questions, if until the end of class the student has not finished working on the questions, then the questions are used as homework.

3. The last stage is the evaluation stage

This stage is very necessary to know the results of implementing this method. At this stage a test or a so-called post test is carried out related to the subjects that have been studied.

Measuring the effectiveness of using the quantum teaching method in accounting learning is the test method. The test is divided into two stages, namely the pre test and post test. The results were then compared between the control class and the experimental class. 


\section{F. Independent Sample T-Test}

From the results of the independent sample T-Test, it is known that the test results are in the table below.

Independent Samples Test

\begin{tabular}{|c|c|c|c|c|c|c|c|c|c|}
\hline & \multicolumn{2}{|c|}{$\begin{array}{l}\text { Levene's } \\
\text { Test for } \\
\text { Equality of } \\
\text { Variances }\end{array}$} & \multicolumn{7}{|c|}{ t-test for Equality of Means } \\
\hline & \multirow[t]{2}{*}{$\mathrm{F}$} & \multirow[t]{2}{*}{ Sig. } & \multirow[t]{2}{*}{$\mathrm{t}$} & \multirow[t]{2}{*}{$\mathrm{df}$} & \multirow[t]{2}{*}{$\begin{array}{l}\text { Sig. } \\
(2- \\
\text { tailed })\end{array}$} & \multirow[t]{2}{*}{$\begin{array}{l}\text { Mean } \\
\text { Differen } \\
\text { ce }\end{array}$} & \multirow[t]{2}{*}{$\begin{array}{c}\text { Std. } \\
\text { Error } \\
\text { Differe } \\
\text { nt } \\
\text { ce }\end{array}$} & \multicolumn{2}{|c|}{$\begin{array}{c}95 \% \\
\text { Confidence } \\
\text { Interval of } \\
\text { the } \\
\text { Difference }\end{array}$} \\
\hline & & & & & & & & $\begin{array}{c}\text { Lowe } \\
r\end{array}$ & $\begin{array}{c}\text { Upp } \\
\text { er }\end{array}$ \\
\hline \multirow{2}{*}{$\begin{array}{c}\text { Scor } \\
\text { Equal variances } \\
\text { assumed Equal } \\
\text { ariances not assumed }\end{array}$} &, 573 & 452 & $\begin{array}{c}30 \\
393\end{array}$ & 68 &, 000 & 29,429 & , 968 & $\begin{array}{c}27,49 \\
6\end{array}$ & $\begin{array}{c}31,3 \\
61\end{array}$ \\
\hline & & & $\begin{array}{c}30 \\
393\end{array}$ & $\begin{array}{c}66,3 \\
07\end{array}$ &, 000 & 29,429 &, 968 & $\begin{array}{c}27,49 \\
6\end{array}$ & $\begin{array}{c}31,3 \\
62\end{array}$ \\
\hline
\end{tabular}

Source: SPSS 22 output

From the results of the independent sample T-Test above, the writer can conclude that there are significant differences between students who get the implementation of the method quantum teaching compared with students who did not get the implementation of the quantum teaching method. It is known from the results of the data processing above, where the Sig. (2-tailed), namely $0.00<0.05$ with a confidence level of $95 \%$, so there is a significant difference between the two classes.

Analysis of the Effect of the Implementation... 


\section{G. Linearity Test}

\begin{tabular}{|c|c|c|c|c|c|}
\hline \multicolumn{6}{|c|}{ ANOVA Table } \\
\hline & $\begin{array}{l}\text { Sum of } \\
\text { Squares }\end{array}$ & Df & $\begin{array}{l}\text { Mean } \\
\text { Square }\end{array}$ & & Sig. \\
\hline \multirow{6}{*}{$\begin{array}{c}\mathrm{Y}{ }^{*} \mathrm{X} 1 \text { Between Groups (Combined) } \\
\text { Linearity Deviation from Linearity } \\
\text { Within Groups Total }\end{array}$} & & 4 & & &, 563 \\
\hline &, 019 & 1 &, 019 & 042 &, 840 \\
\hline & 1,351 & 3 & , 450 & & , 411 \\
\hline & & & & & \\
\hline & 11,297 & 25 &, 452 & & \\
\hline & 12,667 & 29 & & & \\
\hline
\end{tabular}

Source: SPSS output 22

Based on the results of the ANOVA linearity table above, it can be concluded that:

1. Based on the Significance value (Sig):

From the output above, the value of Deviation from Linearity Sig. is 0.411 greater than 0.05 . Then it can be concluded that there is a significant linear relationship between the methods of quantum teaching practices $(X)$ with accounting learning $(Y)$.

2. Based on the value of $F$ :

From the above output, the calculated $F$ value is $0.996<F$ table 2.99 . Because the calculated $F$ value is smaller than the $F$ value of the table, it can be concluded that there is a significant linear relationship between the quantum teaching method $(X)$ with accounting learning $(\mathrm{Y})$.

\section{Conclusion}

From the research results that have been discussed above, then by implementing the quantum teaching method, it will be able to increase the output of accounting learning outcomes, and will also be able to increase the learning value of a student in class XI-IPS SMA N 1 Laguboti. This is evident from the results of the $t$ test and the results of the linearity test, where there are significant differences between the two classes studied. and suggestions Based on research results regarding accounting learning that has been obtained, the authors suggest that educators or teachers can implement the quantum teaching learning method so that later it can increase the output of accounting learning outcomes. For further researchers, it is hoped that they will be able to improve and add to the aspects observed in increasing accounting learning so that it can show an increase in the overall output of accounting learning outcomes, and be able to examine student responses to the implementation of the quantum teaching model. 


\section{References}

[1] A. Abdurrahman, A. Saregar, and R. Umam, "The effect of feedback as soft scaffolding on ongoing assessment toward the quantum physics concept mastery of the prospective physics teachers," Jurnal Pendidikan IPA Indonesia, vol. 7, no. 1, pp. 41-47, 2018.

[2] M. S. Akbar and J. A. Pramukantoro, "Pengaruh Model Quantum Teaching Terhadap Motivasi Siswa pada Standar Kompetensi Dasar-Dasar Elektronika di SMK Nu Sunan Drajat Paciran Lamongan," Jurnal Pendidikan Teknik Elektro, vol. 3, no. 1, 2014.

[3] G. Hamdu and L. Agustina, "Pengaruh motivasi belajar siswa terhadap prestasi belajar IPA di sekolah dasar," Jurnal penelitian pendidikan, vol. 12, no. 1, pp. 90-96, 2011.

[4] A. Sudijono, Pengantar statistik pendidikan. PT Raja Grafindo Persada, 2005.

[5] S. Arikunto, "Prosedur Penelitian Pendidikan Suatu Pendekatan Praktik," Jakarta: Rineka Cipta, 2010.

[6] S. Bahri, "Pengantar akuntansi berdasarkan SAK ETAP dan IFRS," 2017.

[7] A. T. Gurning, "MODEL PEMBELAJARAN JIGSAW UNTUK MENINGKATKAN KREATIVITAS TARI BERPOLA RANDAI PADA SISWA KELAS VIII-2 DI SMP NEGERI 13 MEDAN TP. 2018/2019," Gesture: Jurnal Seni Tari, vol. 8, no. 2, pp. 193-205.

[8] M. Isnaini and I. Wigati, "Pengaruh Model Pembelajaran Quantum Teaching dengan Langkah-Langkah Tandur terhadap Keterampilan Proses Belajar Siswa Materi Sel Kelas Xi di SMA Muhammadiyah 1 Palembang," Bioilmi: Jurnal Pendidikan, vol. 2, no. 1, 2016.

[9] M. Pendidikan Nasional, "Undang Undang No 20 tahun 2003 tentang system pendidikan Nasional," 2010.

[10] B. DePorter, M. Reardon, and S. Singer-Nourie, Quantum teaching: mempraktikkan quantum learning di ruang-ruang kelas. Kaifa, 2010.

[11] N. Suryani, "Improvement of students' history learning competence through quantum learning model at senior high school in Karanganyar Regency, Solo, Central Java Province, Indonesia," Journal of Education and Practice, vol. 4, no. 14, pp. 55-63, 2013.

[12] F. Andriani, "Teori belajar behavioristik dan pandangan islam tentang behavioristik," Syaikhuna: Jurnal Pendidikan dan Pranata Islam, vol. 6, no. 2, pp. 165-180, 2015. [13] N. A. Faj, J. Fakhri, and A. D. Yusandika, "Efektifitas Model Pembelajaran Quantum Teaching dengan Metode Praktikum terhadap Hasil Belajar Peserta Didik," Indonesian Journal of Science and Mathematics Education, vol. 1, no. 2, pp. 135-141, 2018.

[14] S. Fatmawati, Desain Laboratorium Skala Mini untuk Pembelajaran Sains Terpadu. Deepublish, 2015.

[15] K. Susiani, N. Dantes, and N. Tika, "Pengaruh model pembelajaran quantum terhadap kecerdasan sosio-emosional dan prestasi belajar IPA siswa kelas V SD di Banyuning," PENDASI: Jurnal Pendidikan Dasar Indonesia, vol. 3, no. 1, 2013.

[16] P. B. Dan, T. I. Umum, S. P. B. Dan, T. I. K. TIK, and T. Referensi, "Proses Belajar Mengajar," 2009.

[17] C. G. Industry, N. P. Margin, F. S. Asset, and E. P. Share, "Arifin, S. dan Asyik, NF 2015.'Pengaruh Profitabilitas, Likuiditas, Growth Potential, Dan Kepemilikan Manajerial Terhadap Kebijakan Dividen'. Jurnal IImu \& Riset Akuntansi Vol. 4 No. 2, 2-17. Baramuli, Dedy Natanael. 2016."Pengaruh Likuiditas Dan Profitab," Journal S1 AK Universitas Pendidikan Ganesha Vol,

Analysis of the Effect of the Implementation... 
vol. 3, no. 1, 2015.

[18] K. Kokom, "Pembelajaran kontekstual konsep dan aplikasi," Bandung: PT Refika Aditama, 2014.

[19] S. Rohanah, "Penerapan model quantum teaching pada pembelajaran PKn untuk meningkatkan aktivitas dan hasil belajar siswa kelas IV SDN Pungging Pasuruan," Penerapan model quantum teaching pada pembelajaran PKn untuk meningkatkan aktivitas dan hasil belajar siswa kelas IV SDN Pungging Pasuruan/Siti Rohanah, 2016.

[20] A. P. Ningrum and A. D. Lesmono, "Pengembangan Bahan Ajar Berupa Modul Berbasis Quantum Teaching pada Pembelajaran Fisika di SMA," Jurnal Pembelajaran Fisika, vol. 5, no. 4, pp. 315-320, 2017.

[21] C. Chotimah and M. Fathurrohman, "Paradigma Baru Sistem Pembelajaran." AR-RUZZ MEDIA, 2018.

[22] S. Sagala, "Supervisi Pendidikan dalam Profesi Pendidikan." Bandung. Penerbit Alfabeta, 2010.

[23] W. Sanjaya, "Strategi pembelajaran berorientasi standar proses pendidikan," 2019. [24] U. Sekaran and R. Bougie, Research methods for business: A skill building approach. John Wiley \& Sons, 2016.

[25] F. Abdillah, "Penggunaan Modul sebagai Upaya Peningkatan Hasil Belajar Siswa dalam Mata Pelajaran TIK pada Materi Microsoft Word Kelas V SDN Sarikarya," Jurnal Elektronik Pendidikan Teknik Informatika, vol. 2, no. 1, p. 20, 2013.

[26] S. Haryati, "Research and Development (R\&D) sebagai salah satu model penelitian dalam bidang pendidikan," Majalah Ilmiah Dinamika, vol. 37, no. 1, p. 15, 2012.

[27] P. Sugiyono, "Metode penelitian kombinasi (mixed methods)," Bandung: Alfabeta, 2015.

[28] A. R. Hidayat and E. Junianto, "Pengaruh gadget terhadap prestasi siswa smk yayasan islam tasikmalaya dengan metode tam," Jurnal Informatika, vol. 4, no. 2, 2017. [29] S. Sumaryati, "Pengaruh Model Pembelajaran Quantum Learning Terhadap Prestasi Belajar Mata Kuliah Dasar Akuntansi Dengan Memperhatikan Emotional Quotient (EQ) dan Motivasi Berprestasi," ED EQUILIBRIUM, vol. 1, no. 1, 2013.

[30] R. A. Suryadi and A. Mushlih, Desain dan perencanaan pembelajaran. Deepublish, 2019. [31] R. I. Undang-Undang, "no. 20 tahun 2003 tentang Sistem Pendidikan Nasional," Bandung: Citra Umbara, 2003.

[32] M. Wena, "Strategi pembelajaran inovatif kontemporer suatu tinjauan konseptual operasional," Jakarta: bumi aksara, 2009.

[33] T. Hariguna, M. Yusup, and A. Priyadi, "The Transaction Optimization Of Color Print Sales Through E-Commerce Website Based On Yii Framework On Higher Education," Aptisi Transactions On Technopreneurship (ATT), vol. 1, no. 1, pp. 1-10, 2019. [34] S. Santoso, J. Kauf, and N. C. Aristo, "The Information System of Name Card Sales Based on Digital Marketing to Improve Creativepreneur on College E-Commerce Website," Aptisi Transactions On Technopreneurship (ATT), vol. 1, no. 1, pp. 64-72, 2019.

[35] P. A. Sunarya, D. D. Bernard, and D. M. Damanik, "Viewboard Implementation Based on Javascript Charts as a Media for Submitting Sales Information on a Green E-Commerce Website Light Cafe," Aptisi Transactions On Technopreneurship (ATT), vol. 1, no. 1, pp. 11-19, 2019. 
[36] M. Zarlis, E. P. Harahap, and L. N. Husna, "Test Appraisal System Application Based on YII Framework as Media Input Student Value Final Project and Thesis Session at Higher Education," Aptisi Transactions On Technopreneurship (ATT), vol. 1, no. 1, pp. 73-81, 2019. 